\title{
Molecular deletion analysis in Duchenne muscular dystrophy
}

\author{
N S T THOMAS*, P N RAY $\dagger, R$ G WORTON†, AND \\ P S HARPER* \\ From * the Section of Medical Genetics, University of Wales College of Medicine, Heath Park, Cardiff; and \\ the Department of Genetics and Research Institute, Hospital for Sick Children, and Department of Medical \\ Genetics, University of Toronto, Ontario, Canada M5G 1 X8.
}

SUMMARY Study of 165 unrelated patients with $\mathrm{X}$ linked muscular dystrophy (117 with Duchenne and 48 with Becker dystrophy) has shown nine Duchenne cases (8\% of the total) where a molecular deletion was detected using probes pERT87 or XJ1.1. No cytogenetic abnormalities were detectable in this unselected series of patients and no clear clinical or other differences were found between deletion and non-deletion cases. No deletions were found in the 48 Becker patients. Analysis of the families allowed unequivocal identification of carrier status in females hemizygous for the deleted allele. Since some of the deletions were detected with only one of the two probes, it is important that both pERT87 and XJ1.1 are used when studying patients for molecular deletions.

Duchenne muscular dystrophy (DMD) is the most frequent and clinically most severe of the $\mathrm{X}$ linked muscular dystrophies. The underlying biochemical lesion is, however, still unresolved and much recent work has centred on localising and defining the defective gene locus, using several different molecular and cytogenetic mapping techniques. These studies have localised the DMD gene and also the gene for the milder Becker muscular dystrophy to the Xp21 region on the short arm of the $X$ chromosome.

Cytogenetic analysis, using high resolution banding of prometaphase chromosomes, has indicated that various $\mathrm{X}$ chromosome rearrangements that involve the Xp21 region, including translocations and interstitial deletions, are responsible for the expression of the disease state. More than 12 different de novo $\mathrm{X}$; autosomal translocations, each with an identifiable breakpoint within the Xp21 band, have been reported in isolated female patients exhibiting a Duchenne or Becker-like form of the disease.$^{1-3}$ Recently, a number of male Duchenne patients have been reported who exhibit small interstitial chromosomal deletions involving the Xp21 region. These patients show a classical Duchenne phenotype but also normally have the

Received for publication 30 June 1986.

Revised version accepted for publication 8 August 1986 clinical features of several other $\mathrm{X}$ linked disorders. One such group of patients, with Xp21.1 $\rightarrow$ p22.0 deletions, have adrenal hypoplasia, glycerol kinase deficiency, and severe mental retardation. ${ }^{47}$ Another Duchenne boy, with a discrete deletion encompassing the $X \mathrm{p} 21 \cdot 1 \rightarrow \mathrm{p} 21 \cdot 3$ region, presented with chronic granulomatous disease, retinitis pigmentosa, and severe mental retardation, but with no evidence of either adrenal hypoplasia or glycerol kinase deficiency. ${ }^{8}$

Extensive genetic linkage analysis carried out in Duchenne and Becker families, using a panel of polymorphic DNA probes whose loci have been independently mapped to positions both proximal and distal to the Xp21 region, has complemented the cytogenetic studies and has clearly localised the genes for these disorders to this particular region of the $\mathrm{X}$ chromosome. ${ }^{9-11}$ Indeed, the similarity of the linkage results for both disorders indicates that the loci for both diseases are either closely linked or even allelic, as originally proposed by Becker and Kiener. ${ }^{12}$

Several of the patients with these chromosomal rearrangements have been used to construct different genomic DNA libraries from which DNA probes very closely linked to the DMD and BMD loci have been identified. DNA from the Duchenne deletion patient of Francke et $a l^{8}$ has been used to construct a subchromosomal library enriched for 
sequences that map directly to the deletion region at $\mathrm{Xp} 21 \cdot 2 .{ }^{13}$ This 'pERT' library has yielded eight different human sequences which map within this deleted region and chromosome 'walking' with these probes has identified a further $150 \mathrm{~kb}$ of adjacent genomic DNA. When used to screen a panel of more than 50 different Duchenne and Becker DNA samples, one of these probes, identified as pERT87, consistently failed to hybridise to DNA from five subjects. ${ }^{14}$ Recently, Worton et al, ${ }^{15}$ using the observation that the translocation breakpoint in a female Becker patient with a de novo X;21 translocation involved the ribosomal gene family located on the short arm of chromosome 21 , have used various ribosomal gene probes to identify successfully and clone the DNA sequence involved in this translocation breakpoint. ${ }^{16}$ This probe, $\mathrm{XJ} 1 \cdot 1$, also identifies molecular deletions in Duchenne patients and it was found that all five deletion patients originally identified by pERT87 were also deleted for probe $\mathrm{XJ} 1 \cdot 1$.

In this study we have used three genomic subclones of the original pERT87 (pERT87-1, 87-8, and $87-15)$ and also probe XJ1.1 to examine our extensive panel of DNA samples from Duchenne and Becker muscular dystrophy patients for evidence of molecular deletions. We have also used the several restriction fragment length polymorphisms associated with the pERT87 probes to evaluate the carrier status of female members within those families found to exhibit a DNA deletion.

\section{Methods}

PATIENTS STUDIED

The Duchenne patients were principally those living in Wales, where a total population study has been undertaken by us. Patients from outside Wales were those from large kindreds forming part of our previous genetic linkage studies ${ }^{11}$ and also those studied for carrier detection. ${ }^{17}$ Becker muscular dystrophy patients were principally from families showing clear $X$ linked inheritance in at least two generations, who had formed part of the study of Kingston et al. ${ }^{10}$ A smaller proportion were referrals for genetic counselling subsequent to this study.

DNA ANALYSIS

DNA extraction from venous blood, restriction enzyme digests, and hybridisation protocols have been reported previously. ${ }^{11}$ Radiolabelling of human inserts excised from the probes was either by nick translation using a commercial kit (Amersham, UK) or by a random hexanucleotide primed polymerase method ${ }^{18}$ to give specific activities of $10^{7}$ to $10^{8} \mathrm{dpm} / \mu \mathrm{g}$ DNA. Southern blotting of digested
DNA was onto either Gene Screen Plus (Dupont) or Hybond-N (Amersham) and suitable hybridisation buffers were used.

DNA PROBES

The three probes, pERT $87-1,87-8$, and $87-15$, are derived from unique sequences present within a contiguous $45 \mathrm{~kb}$ of genomic DNA. They are usefully polymorphic with several different restriction enzymes: pERT87-1 with BstNI and XmnI, pERT87-8 with TaqI and BstXI, and pERT87-15 with TaqI and XmnI.

Probe $\mathrm{XJ} 1 \cdot 1$ is derived from a unique sequence present on the $X$ chromosomal sequences adjacent to the translocation breakpoint in the female patient with an $\mathrm{X} ; 21$ translocation. This probe is polymorphic with TaqI.

DELETION AND DOSAGE ANALYSIS

All the probes used in this study give a single hybridising band with PstI. Genomic DNA (5 $\mu \mathrm{g})$ was digested with this enzyme and the restriction fragments separated by electrophoresis through an $\mathbf{0 . 8 \%}$ agarose gel. Each DNA test track was bracketed by a track containing a similar digest of either normal male or female DNA. Special care was taken to measure accurately and adjust all DN concentrations to ensure the same amount of DNA per digest. The DNA was blotted onto either GeneScreen Plus or Hybond- $\mathrm{N}$ and then either baked at $80^{\circ} \mathrm{C}$ for two hours or irradiated with $305 \mathrm{~nm} \mathrm{UV}$ light to immobilise the DNA onto the filter.

The filter was hybridised simultaneously with pERT87-8 and L1 28 . The latter probe, localised to $\mathrm{Xp} 11.3$ and therefore well outside the proposed deleted region, serves as an internal control to monitor any variation in DNA concentration between samples. After suitable post-hybridisation washes, normally down to $0.5 \times$ SSC for 30 minutes at $65^{\circ} \mathrm{C}$, the filter was exposed to Fuji $X$-ray film at $-70^{\circ} \mathrm{C}$ for 24 to 48 hours with intensifying screens.

Although using this method we have observed a degree of gene dosage in hemizygous females (fig 1), we have found that quantitative dosage analysis has been difficult to demonstrate reliably. Using laser densitometric measurements of such autoradiographs we have found quite wide variations in our analysis. We are currently examining the possible basis for these fluctuations and are modifying the methodology of Tantravahi et $a l^{19}$ to optimise these dosage measurements.

\section{Results}

DELETION SCREENING

A total of 117 Duchenne and 48 Becker patients, all 

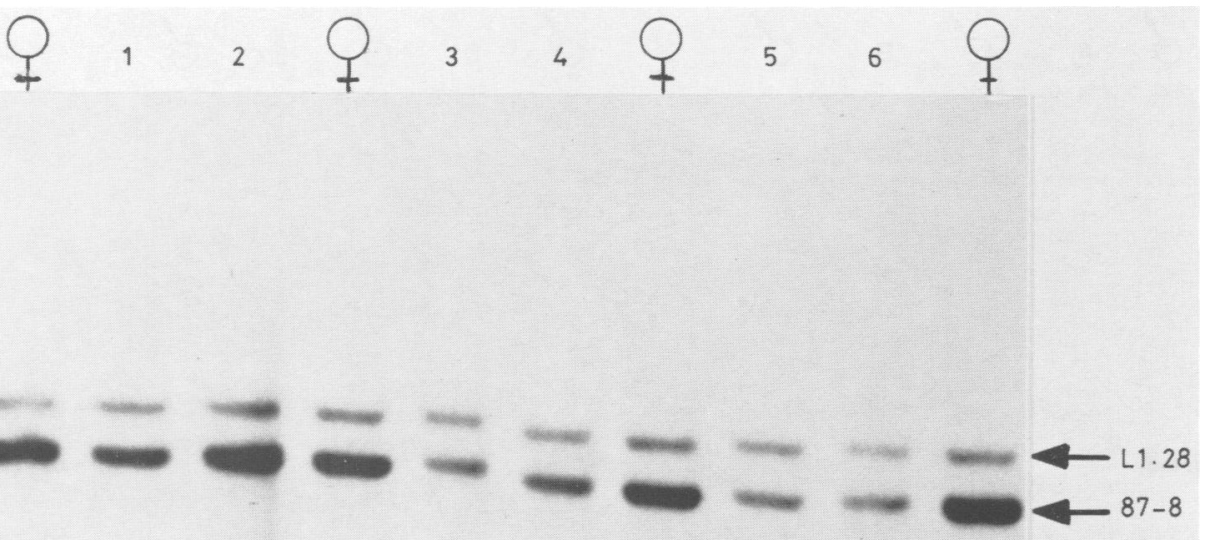

FIG 1 Gene dosage analysis on females from DMD deletion families. PstI digested DNA from either six test females or normal female controls was hybridised simultaneously with pERT87-1 and L1.28. A 'dosage effect' can clearly be seen in females 3, 4, 5, and 6, but females 1 and 2 appear to exhibit a normal female hybridisation pattern.

unrelated, was studied with the two probes pERT87 and $\mathrm{XJ} 1 \cdot 1$. We identified nine Duchenne deletion patients (table 1), four of whom were included in the pooled data reported by Kunkel et al. ${ }^{20}$ Five were deleted for all three pERT probes, four were deleted for $\mathrm{XJ} 1 \cdot 1$ alone, and only one Duchenne patient was deleted for both pERT87 and XJ1.1. None of these patients was deleted for either the proximal probe 754 or the more distal probe $\mathrm{C} 7$. No deletions were found in the 48 Becker patients examined. A typical pERT screening filter is shown in fig 2. Pst I digested DNA from five deletion patients and six normal male controls was hybridised with both pERT87-8 and L1.28.

Table 2 summarises the clinical features of the deletion cases, which show no significant differences from those of non-deletion patients. One further patient from outside our region, not included in this series and reported elsewhere, ${ }^{7}$ was studied specifi- cally because of the additional presence of Addison's disease and severe mental retardation. He exhibited a discrete chromosomal deletion in the region $\mathrm{Xp} 21 \cdot 2 \rightarrow \mathrm{p} 22 \cdot 2$. His DNA was deleted not only for both pERT87 and XJ1.1 but also for the

TABLE 1 DMD patients showing a molecular deletion.

\begin{tabular}{lllll}
\hline Case & $\begin{array}{l}\text { pERT87 } \\
\text { deletion }\end{array}$ & $\begin{array}{l}\text { XI1 } \\
\text { deletion }\end{array}$ & $\begin{array}{l}\text { Cytogenetic } \\
\text { deletion }\end{array}$ & $\begin{array}{l}\text { Familial } \\
\text { isolated }\end{array}$ \\
\hline 1 & Yes & - & - & Isolated \\
2 & Yes & - & - & Isolated \\
3 & Yes & - & - & Familial \\
4 & Yes & - & - & Familial \\
5 & - & Yes & - & Isolated \\
6 & - & Yes & - & Familial \\
7 & - & Yes & - & Isolated \\
8 & - & Yes & - & Isolated \\
9 & Yes & Yes & - & Familial \\
\hline
\end{tabular}




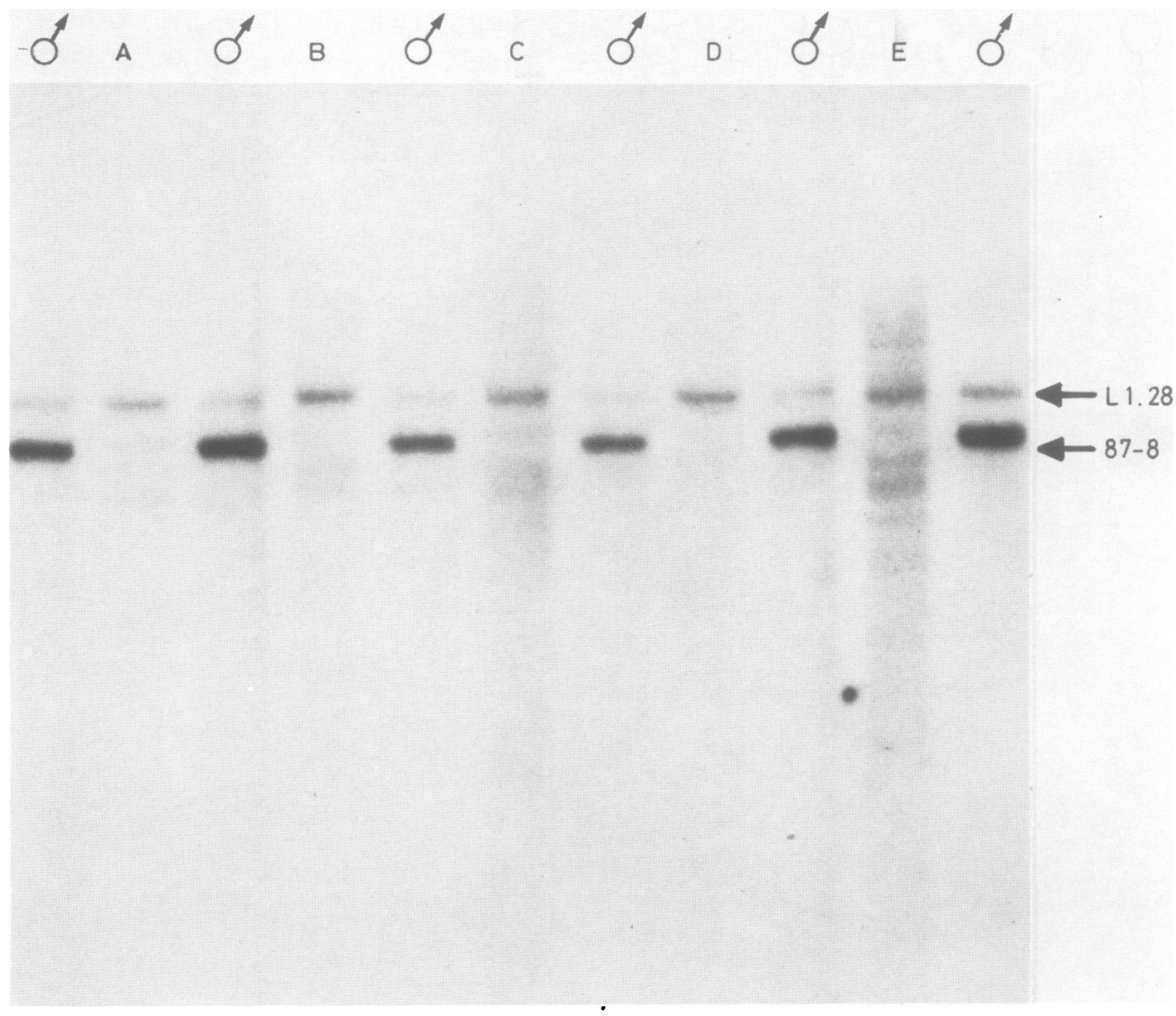

FIG 2 PstI digested DNA from five DMD deletion patients and six normal male controls was hybridised simultaneously with $p$ ERT87-1 and L1.28.

TABLE 2 Clinical features of patients tested for molecular deletions.

\begin{tabular}{|c|c|c|c|}
\hline & $\begin{array}{l}\text { Duchenne } \\
\text { (no deletion) }\end{array}$ & $\begin{array}{l}\text { Duchenne } \\
\text { (deletion) }\end{array}$ & Becker \\
\hline $\begin{array}{l}\text { Familial } \\
\text { Isolated* } \\
\text { Uncertain }\end{array}$ & $\begin{array}{r}53 \\
54 \\
1\end{array}$ & $\begin{array}{l}4 \\
5\end{array}$ & $\begin{array}{r}36 \\
11 \\
1\end{array}$ \\
\hline $\begin{array}{l}\text { Mean age in } \\
\text { wheelchair } \\
\text { (y) }\end{array}$ & $\begin{array}{l}10 \\
\text { (of 40) }\end{array}$ & $\begin{array}{l}10 \\
(\text { of } 6)\end{array}$ & $\begin{array}{l}38 \\
(\text { of } 6)\end{array}$ \\
\hline $\begin{array}{l}\text { Mean age } \\
\text { at death } t \\
\text { (y) }\end{array}$ & $\begin{array}{c}18 \\
\text { (of 25) }\end{array}$ & $\begin{array}{l}21 \\
(\text { of } 6)\end{array}$ & $\begin{array}{l}40 \\
\text { (of 2) }\end{array}$ \\
\hline $\begin{array}{l}\text { Mental } \\
\text { retardation } \\
\text { (where known) }\end{array}$ & $\begin{array}{l}14 \text { of } 57 \\
(25 \%)\end{array}$ & $\begin{array}{l}4 \text { of } 10 \\
(40 \%)\end{array}$ & $\begin{array}{l}2 \text { of } 20 \\
(10 \%)\end{array}$ \\
\hline $\begin{array}{l}\text { Total } \\
\quad \text { families } \\
\text { tested }\end{array}$ & 108 & 9 & 48 \\
\hline
\end{tabular}

*Isolated case defined as one where only one affected male known in a family, regardless of carrier status of female relatives.

tMean age at death included the ages at death of affected family members of those tested. Most patients who have been tested are still alive. proximal probe 754 and the more distal probe $\mathrm{C} 7$. Prometaphase chromosome studies on four living pERT deletion cases were performed and showed no observable abnormality.

The results of a gene dosage analysis screen with pERT87-8 and L1.28 in females from deletion families is shown in fig 1 . The DNA in test lanes 3 , 4,5 , and 6 are from the four females I.2, II.2, III.3, and III.4, identified in the pedigree in fig 3 . In this family, subjects III. 3 and III. 4 , the two sisters of the affected boy, had very high CK results, giving carrier risks of $99 \%$. A DNA sample from a previous chorion biopsy, identified as a male fetus, was available from the pregnancy of one of these sisters. (III.3) and showed a normal pERT87-8 hybridising band, indicating that normal and affected males can be specifically identified in such families.

Although great care was taken to ensure that similar amounts of DNA were used in each test and 


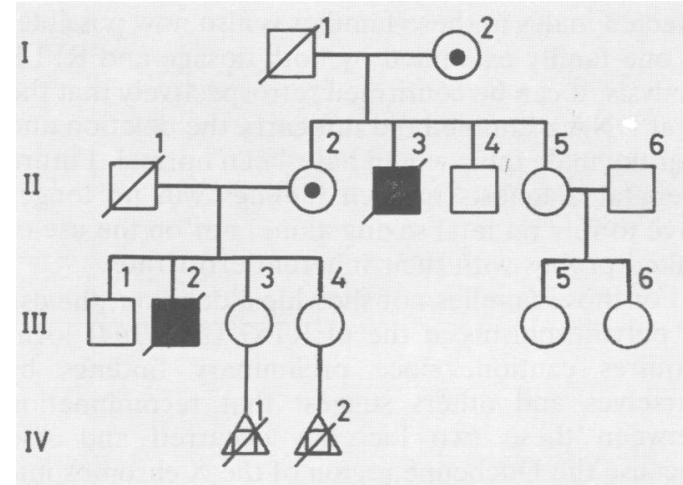

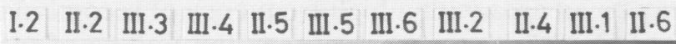

FIG 3 Anomalous inheritance of alleles for the XmnI polymorphism with pERT87-15 in members of a familial $D M D$ deletion family indicating hemizygosity for this probe in several female members. Note the apparent homozygosity for the different alleles in females I.2, her daughters II.2, and II.5, and her two grand-daughters, III.3 and III.4, indicating the obligate carrier status of all five females.

control track, we have found it difficult to measure gene dosage reliably, especially when analysed by densitometry. It was for this reason that we initiated the analysis of pERT87 RFLP allele distribution in these deletion families.

\section{DNA POLYMORPHISMS}

The various subclones of pERT87 show polymorphisms with several restriction enzymes and use of these has helped to identify those females hemizygous for the deletion. In fig 3 we have used a family previously examined by dosage analysis to demonstrate the inheritance of the deletion through the pedigree using the XmnI polymorphism with pERT87-15.

The obligate grandmother (I.2) is apparently homozygous for allele 1 and has passed this allele on to her normal son (II.4). However, both her daughters, II.5, a possible carrier, and II.2, an obligate carrier, are apparently homozygous for allele 2, which female II.2 passed on to her normal son (III.1), while the deleted $\mathrm{X}$ chromosome was inherited by her affected son (III.2). Her two daughters (III.3 and III.4) are apparently homozygous for allele 1 , which was also inherited by the male fetus (IV.1). This apparently unusual pattern of allele inheritance clearly indicates that all the females so far examined in this family are hemizygous for the deletion, as they only express their paternally derived alleles and hence they may all be considered to be carriers of the Duchenne gene. We have recently examined the two daughters of subject II.5, already shown to be a carrier. However, both girls express allele 2 , the same allele as their mother, and as their father also carries allele 2 we are unable to establish their carrier status with this particular RFLP.

In fig 4 we have used the $X m n I$ polymorphism with pERT $87-1$ to follow the allele distribution in the family members of an isolated pERT deletion

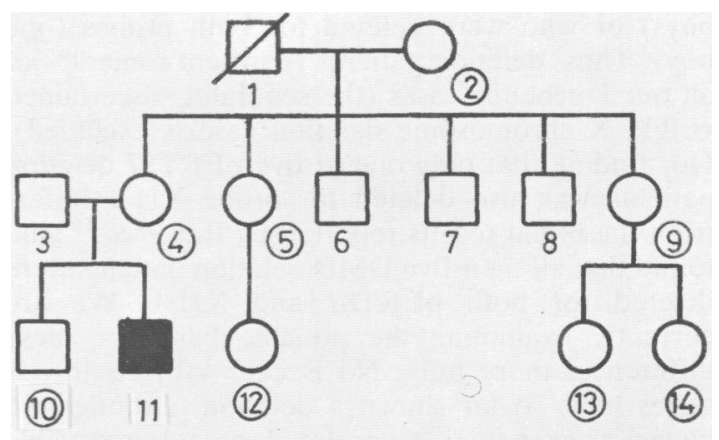

PERT $87-1(X m \cap I)$
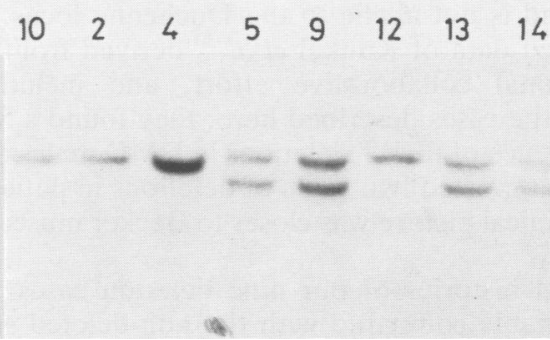

FIG 4 Inheritance of the alleles of the XmnI polymorphism with pERT87-1 in various members of an isolated DMD deletion family. Female 4 has apparently not inherited an allele from her dead father (1), indicating her obligate carrier status. His genotype was inferred from that of his two daughters (5 and 6), who are heterozygous for this particular probe and hence are normal. 
patient. The grandmother (2) in this family is apparently homozygous for allele 1 , as is her first daughter (4), the mother of the affected boy. Her other two daughters (5 and 9) are, however, heterozygous for this RFLP and from this we can infer that their dead father (1) must have possessed allele 2 for this polymorphism and that these daughters therefore do not carry the deletion. However, this paternal allele 2 was apparently not passed onto (4) and, assuming correct paternity, and the distribution of alleles of five flanking DNA probes would tend to support paternity, then (4) must have received allele 1 from her mother, which she subsequently passed onto her normal son (10). She received a deleted $\mathrm{X}$ chromosome from her father as a new mutation, which she then passed onto her affected son (11).

\section{Discussion}

We have identified nine DMD males from a series of 117 patients tested, who were deleted for either pERT87 alone (four boys) or for XJ1.1 alone (four boys) or who were deleted for both probes (one boy). Thus, deletion patients represent some $9 \%$ of all our Duchenne cases (the separately ascertained visible $\mathrm{X}$ chromosome deletion case is excluded). Our finding that only one of five pERT87 deletion patients was also deleted for probe XJ1.1 differs from the initial results reported by Ray et al, ${ }^{16}$ who found that all their five DMD deletion patients were deleted for both pERT87 and XJ1.1. We are currently examining the possible basis for these differences more fully. No Becker subjects in our series have so far shown a deletion, although we have now examined 48 unrelated cases. It is possible that a complete gene deletion would normally produce the more severe Duchenne phenotype or, alternatively, that the Becker locus is only closely linked and is not allelic to the Duchenne locus. In the pooled data of Kunkel et al, ${ }^{20}$ derived from an international collaborative effort, and including some of the cases described here, they found a 5 to $7 \%$ incidence of pERT deletions in DMD males and they also reported two cases of deletions in patients whose clinical picture was closer to Becker muscular dystrophy.

Clinical histories of our nine deletion cases are unremarkable compared with the non-deleted subjects. None of the pERT 87 or XJ1.1 deletion families showed a visible $\mathrm{X}$ chromosome deletion, apart from the single specially ascertained case mentioned previously.

The use of gene dosage and RFLP analysis within these deletion families has allowed conclusive identification of carrier females; prenatal diagnosis of affected males in these families is also now possible. In one family examined by both dosage and RFLP analysis, it can be confirmed retrospectively that the fetal DNA examined did not carry the deletion and that the male fetus would have been normal. Future prenatal diagnosis in such families will no longer have to rely on fetal sexing alone, nor on the use of linked probes with their inherent error rate.

For those families not showing a deletion, the use of polymorphisms at the pERT87 (DXS164) locus requires caution, since preliminary findings by ourselves and others suggest that recombination between these two loci has occurred and also because the Duchenne region of the $\mathrm{X}$ chromosome may be an area with a high frequency of recombination. Despite these reservations, the finding of two independently isolated DNA sequences sufficiently close to the Duchenne gene to show a molecular deletion in 5 to $10 \%$ of cases is a major advance, both towards isolation of the gene itself and in allowing prenatal diagnosis and carrier detection for the families concerned.

We thank Dr L Kunkel of Boston Children's Hospital for the gift of the pERT87 probes, our clinical colleagues, in particular Drs Angus Clarke Helen Kingston, Jo Sibert, and Hywel Williams, fo their help in studying patients, Selwyn Roberts foet the cytogenetic analyses, and Kim Roberts for skilled technical assistance. This work was supported by the Muscular Dystrophy Group of Great Britain and the Muscular Dystrophy Association of America.

\footnotetext{
References

1 Lindenbaum RH, Clarke G, Patel C, Moncrieff M, Hughes JT. Muscular dystrophy in an $\mathrm{X} ; 1$ translocation female suggests that Duchenne locus is on $\mathrm{X}$ chromosome short arm. $J$ Med Genet 1979;16:389-92.

2 Jacobs PA, Hunt PA, Mayer M, Bart RD. Duchenne muscular dystrophy (DMD) in a female with an X-autosomal translocation: further evidence that the DMD locus is at Xp21. Am J Hum Genet 1981;33:513-8.

3 Verrellen-Dumoulin C, Freund M, De Meyer R, et al. Expression of an X-linked muscular dystrophy in a female due to a translocation involving $\mathrm{Xp21}$ and non-random inactivation of the normal X-chromosome. Hum Genet 1984;67:115-9.

${ }^{4}$ Weiringa B, Hustinx T, Scheres J, Renier W, ter Haar B. Complex glycerol kinase deficiency syndrome explained as an X-chromosomal deletion. Clin Genet 1985;27:522-3.

${ }^{5}$ Bartley JA, Patil S, Davenport S, Goldstein D, Pickens J. Duchenne muscular dystrophy, glycerol kinase deficiency and adrenal insufficiency associated with an $\mathrm{Xp} 21$ interstitial deletion. J Pediatr 1986;108:189-92.

${ }^{6}$ Saito F, Goto J, Kakinuma H, et al. Inherited Xp21 deletion in a boy with a complex glycerol kinase deficiency. Clin Genet 1986;29:92-3.

7 Clarke A, Thomas NST, Roberts SH, Whitfield A, Williams J, Harper PS. Duchenne muscular dystrophy with adrenal insufficiency and glycerol kinase deficiency: high resolution cyto-
} 
genetic analysis with molecular, biochemical, and clinical studies. J Med Genet 1986;23:501-8.

${ }^{8}$ Franke U, Ochs HD, de Martinville B, et al. Minor Xp21 chromosome deletion in a male associated with expression of Duchenne muscular dystrophy, chronic granulomatous disease, retinitis pigmentosum and McLeod syndrome. Am J Hum Genet 1985;37:250-67.

${ }^{9}$ Davies KE, Pearson PL, Harper PS, et al. Linkage analysis of two cloned DNA sequences flanking the Duchenne muscular dystrophy locus on the short arm of the human X-chromosome. Nucleic Acids Res 1983;11:2303-12.

${ }^{10}$ Kingston HM, Sarfarazi M, Thomas NST, Harper PS. Localisation of the Becker muscular dystrophy gene to the short arm of the X-chromosome by linkage to cloned DNA sequences. Hum Genet 1984;67:6-17.

${ }^{11}$ Brown CS, Thomas NST, Sarfarazi M, et al. Genetic linkage relationship of seven DNA probes with Duchenne and Becker muscular dystrophies. Hum Genet 1985;71:62-74.

12 Becker PE, Kiener F. Eine neue X-chromosomale Muskeldystrophie. Arch Psychiatr Nervenkr 1955;193:427-48.

${ }^{13}$ Kunkel LM, Monaco AP, Middlesworth W, Ochs HD, Latt SA. Specific cloning of DNA fragments absent from a male patient with an X-chromosome deletion. Proc Natl Acad Sci USA 1985;82:4778-82.

${ }^{14}$ Monaco AP, Bertelson CJ, Middlesworth W, et al. Detection of deletions spanning the Duchenne muscular dystrophy locus using a tightly linked DNA segment. Nature 1985;316:842-5.
15 Worton RG, Duff C, Sylvester JE, Schmickel RD, Willard HF. Duchenne muscular dystrophy involving translocation of the dmd gene next to ribosomal RNA genes. Science 1984;224:1447-8.

${ }^{16}$ Ray PN, Belfall B, Duff C, et al. Cloning of the breakpoint of an $\mathrm{X} ; 21$ translocation associated with Duchenne muscular dystrophy. Nature 1985;318:672-5.

17 Williams H, Sarfarazi M, Brown CS, Thomas NST, Harper PS. The use of flanking markers in prediction for Duchenne muscular dystrophy. Arch Dis Child 1986;61:218-22.

${ }^{18}$ Feinberg AP, Vogelstein B. A technique for radiolabelling DNA restriction fragments to high specific activity. Anal Biochem 1984;137:266-7.

19 Tantravahi U, Kirschner DA, Beauregard L, Page L, Kunkel LM, Latt S. Cytologic and molecular analysis of $46, \mathrm{XXq}-$ cells to identify a DNA segment that might serve as a probe for a putative human X chromosome inactivation centre. Hum Genet 1983;64:33-8.

${ }^{20}$ Kunkel LM, Hejtmancik JF, Caskey CT, et al. Analysis of deletions in DNA from patients with Becker and Duchenne muscular dystrophy. Nature 1986;322:73-7.

Correspondence and requests for reprints to $\mathrm{Dr}$ N S T Thomas, Section of Medical Genetics, University of Wales College of Medicine, Heath Park, Cardiff CF4 4XN. 